recovery test radiology showed that its tip was not lying within the stomach. It is therefore suggested that if a nasogastric tube passes the recovery test one may safely conclude that its tip is within the stomach and that radiological screening is unnecessary.

Examination of the data in Tables II and III shows that there was clearly no significant difference in the mean recoveries of phenol red, acid output, and volume between the two groups-the one with tubes in the so-called optimal position and the other with tubes in the so-called non-optimal position. (It will be noted that five subjects do not appear in Table III. Four of these were patients with gastritis and one had a high gastric ulcer; all five produced practically no acid.) These results show that, under the circumstances of the present study, if the tip of the tube lies in the stomach its exact position within the stomach-whether so-called optimal or nonoptimal-does not affect the completeness of recovery of gastric secretion.

Most workers seem to believe that the tip of the tube should reach below the level of the pool of gastric juice within the stomach if adequate suction is to be achieved, a situation reminiscent of a straw which has to be dipped into the contents of a tumbler. Unlike a tumbler, the stomach is not rigid and its walls probably come closer together under continuous suction, shifting the stomach contents towards the tip of the tube. This is the likely explanation of these results.

Though Table IV shows that recovery of maximal gastric secretion was greater in the left lateral position in certain studies, in others it was greater in the semirecumbent position. The application of the paired Student $t$ test to these results showed that, overall, there was no significant difference between these two positions in the recovery of phenol red, maximal gastric secretion, and acid output (Table V). This result is in line with the preceding evidence that the exact position of the tip of the tube within the stomach does not influence the completeness of recovery and can probably be explained on the same basis-that is, the collapse of the stomach under continuous suction.

\section{Conclusions}

If a nasogastric tube passes the simple water-recovery test its tip is lying within the stomach.

If the tip of the tube lies in the stomach, its exact position, whether so-called optimal or non-optimal, does not affect the recovery of maximal gastric secretion. Therefore, if a nasogastric tube passes the recovery test fluoroscopy is unnecessary.

The position of the subject during the histamine-infusion test does not appreciably affect the recovery of maximal gastric secretion.

These conclusions are contrary to current belief and practice.

\section{REFERENCES}

Baron, J. H. (1963). Gut. 4, 136.

Crawford, G., and Hobsley, M. (1968). Biochemical fournal, 107, 268. Hobsley, M., and Silen, W. (1966). Surgical Forum, 17, 324.

Hobsley, M., and Silen, W. (1969). Gut, 10, 787.

Johnston, D. H., and McCraw, B. H. (1958). Gastroenterology, 35, 512. Lawrie, J. H., Smith, G. M. R., and Forrest, A. P. M. (1964). Lancet, 2, 270. Levin, E., Kirsner, J. B., Palmer, W. R., and Butler, C. (1948). Gastro-

Marks, I. N. (1961). Gastroenterology, 41, 599.

\title{
Relationship of Infantile Vesicoureteric Reflux to Renal Damage
}

\author{
G. L. ROLLESTON, ${ }^{*}$ M.B., D.M.R.D., F.C.R.A., F.F.R.(HON.) ; F. T. SHANNON, $†$ M.B., M.R.C.P., F.R.A.C.P. \\ W. L. F. UTLEY, $\ddagger$ M.B., F.R.C.S., F.R.A.C.S.
}

\begin{abstract}
Cummary: A group of patients known to have had $\checkmark$ vesicoureteric reflux of varying severity in infancy were followed up over a period of five years. Gross vesicoureteric reflux was found to be accompanied by a high incidence of initial and progressive renal damage. Progressive renal damage was not found in infants showing moderate or slight reflux.
\end{abstract}

\section{Introduction}

The association of urinary infection, vesicoureteric reflux, and renal damage has been the subject of much discussion over recent years (Scott and Stansfeld, 1968) and their relationships are still far from clear. It is known that some kidneys subjected to vesicoureteric reflux become progressively damaged while others are apparently unaffected. Why this should be so

*Director of Radiology, Christchurch Hospital, New Zealand.

†Senior Paediatrician, Christchurch Hospital, New Zealand.

$\ddagger$ Senior Urologist, Christchurch Hospital, New Zealand. is a matter of considerable importance because management of the patient will, to a large extent, depend on whether progressive renal changes are likely to occur.

The purpose of this paper is to present a study of a group of patients known to have had vesicoureteric reflux in infancy and to compare the severity of the initial reflux with the incidence of progressive renal damage.

\section{Material and Methods}

Over the period of study all infants who were found to have urinary infection on admission to hospital were investigated by intravenous pyelography and micturating cystourethrography; those with obstructive urinary tract disease were excluded, leaving a total of 175 consecutive patients $(91$ males and 84 females). Their ages at the initial investigation ranged from 3 days to 12 months (Table I). 
TABle I.-Age at Presentation

\begin{tabular}{|c|c|c|c|c|c|c|c|}
\hline \multicolumn{5}{|c|}{ Age } & \multirow{2}{*}{$\begin{array}{c}\text { Males } \\
13 \\
48 \\
30 \\
\end{array}$} & \multirow{2}{*}{$\begin{array}{c}\text { Females } \\
11 \\
26 \\
47 \\
\end{array}$} & \multirow{2}{*}{$\begin{array}{c}\text { Total } \\
24(13.7 \%) \\
74(42.3 \%) \\
77(44 \%) \\
\end{array}$} \\
\hline $\begin{array}{l}1-14 \text { days } \\
2-8 \text { weeks } \\
2-12 \text { months }\end{array}$ & $\begin{array}{l}. \\
\cdots\end{array}$ & $\begin{array}{l}\ldots \\
\cdots \\
\cdots\end{array}$ & $\begin{array}{l}\ldots \\
\cdots \\
\cdots\end{array}$ & $\begin{array}{l}\ldots \\
\cdots\end{array}$ & & & \\
\hline Total & .. & .. & .. & .. & 91 & 84 & 175 \\
\hline
\end{tabular}

Before 1967 the diagnosis of urinary infection was made on the basis of two consecutive midstream urine specimens showing a bacterial count of over 100,000 , but subsequently the technique of direct bladder puncture (Shannon, Sepp, and Rose, 1969) was used.

Every patient in this group was examined at presentation by intravenous pyelography, and particular attention was paid to renal size, caliceal dilatation, and loss of renal substance. The renal outline is difficult to demonstrate in the infant, but in most cases it was defined by using a high-dosage technique (10 to $20 \mathrm{ml}$. of Conray 280 ) and by taking a film as soon as the injection was completed, when nephrographic filling was at its maximum.

The bladder and urethra were examined by micturating cystourethrography when the urinary infection was brought under control. The infant was immobilized on a plywood frame, catheterized, and the bladder filled by gravity with $15 \%$ Urografin. Films were taken during micturition.

\section{Results}

Vesicoureteric reflux was found in $86(49 \%)$ of the 175 infants investigated. It was bilateral in 44 and unilateral in 42 (Table II).

TABLE II.-Vesicoureteric Reflux (175 Infants)

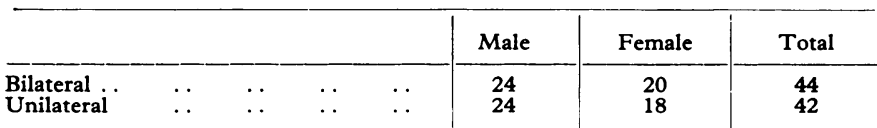

The 130 refluxing ureters were classified into three grades of severity-gross, moderate, and slight. The criteria used for this grading were as follows: Pronounced dilatation of the upper urinary tract during micturition was classified as gross reflux, complete filling of the ureter and pelvi-calicine system without significant dilatation as moderate reflux, and incomplete filling without dilatation as slight reflux (Table III).

TABLE III.-130 Refluxing Ureters (Graded by Severity)

\begin{tabular}{|c|c|c|c|c|c|c|c|}
\hline & & & & & Right Side & Left Side & Total \\
\hline $\begin{array}{l}\text { Gross } \\
\text { Moderate } \\
\text { Slight . . }\end{array}$ & $\begin{array}{l}. \\
\cdots\end{array}$ & $\begin{array}{l}\ldots \\
\ldots\end{array}$ & $\begin{array}{l}\because \\
\therefore\end{array}$ & $\begin{array}{l}\ldots \\
\ldots\end{array}$ & $\begin{array}{l}14 \\
44 \\
12\end{array}$ & $\begin{array}{l}18 \\
30 \\
12\end{array}$ & $\begin{array}{l}32(24 \cdot 5 \%) \\
74(57 \%) \\
24(18 \cdot 5 \%)\end{array}$ \\
\hline
\end{tabular}

The kidneys drained by these refluxing ureters were examined by intravenous pyelography. Anatomical damage was present in $29(22.3 \%)$ kidneys of the 130 refluxing ureters, and all but three of these kidneys were associated with gross reflux. The renal damage. was graded into three degrees of severity-marked, moderate, and slight-and assessed on the basis of the intravenous pyelogram.

A kidney was regarded as severely damaged if there was a substantial loss of renal substance and gross calicine dilatation. In cases of severe unilateral damage the affected kidney was reduced in size and the normal kidney hypertrophied.
Moderate renal damage was diagnosed on the basis of a reduction of kidney size, less severe loss of renal substance, and calicine dilatation. The normal kidney was also hypertrophied in all cases of moderate unilateral damage. Slight renal damage was diagnosed if the length of the kidney was more than 5 $\mathrm{mm}$. less than the normal side and the calices were slightly ballooned. In two instances the damaged kidney showed minor papillary changes but was appreciably enlarged. This was presumably due to oedema from acute pyelonephritis because subsequent examinations showed the kidney to be substantially reduced in size (Little, McPherson, and de Wardener, 1965) (Table IV).

TABLE IV.-Initial Renal Damage Associated with 130 Refluxing Ureters

\begin{tabular}{|c|c|c|c|c|c|c|c|c|}
\hline \multirow{2}{*}{\multicolumn{3}{|c|}{$\begin{array}{l}\text { Grade of } \\
\text { Reflux }\end{array}$}} & \multirow{2}{*}{$\begin{array}{l}\text { Kidneys } \\
\text { Examined }\end{array}$} & \multicolumn{4}{|c|}{ Type of Damage } & \multirow{2}{*}{$\begin{array}{l}\text { Kidneys } \\
\text { Damaged }\end{array}$} \\
\hline & & & & Nil & Slight & Mod. & Marked & \\
\hline $\begin{array}{l}\text { Gross } \\
\text { Moderate } \\
\text { Slight }\end{array}$ & $\begin{array}{l}\cdots \\
\cdots\end{array}$ & $\begin{array}{l}\cdots \\
\cdots\end{array}$ & $\begin{array}{l}32 \\
74 \\
24\end{array}$ & $\begin{array}{r}6 \\
71 \\
24\end{array}$ & $\begin{array}{r}6 \\
3 \\
-\end{array}$ & 듬 & $\frac{4}{-}$ & $\begin{array}{r}26 \\
3 \\
-\end{array}$ \\
\hline Total & .. & . & 130 & 101 & 9 & 16 & 4 & $29(22 \cdot 3 \%)$ \\
\hline
\end{tabular}

\section{Follow-up Intravenous Pyelograms}

Of the 86 infants with vesicoureteric reflux, 34 had the intravenous pyelogram repeated. In this group were $54 \mathrm{kid}-$ neys associated with vesicoureteric reflux which had been reexamined at intervals varying from six months to five years. None of the patients had surgical treatment (Table V).

TABLE V.-Review Period of 54 Reflux Kidneys by Intravenous Pyelography

\begin{tabular}{c|c|c|c|c|c}
\hline 6 months & 1 year & 2 years & 3 years & 4 years & 5 years \\
\hline 6 & 8 & 12 & 4 & 9 & 15
\end{tabular}

A diagnosis of progressive renal damage was made if renal growth had been depressed and/or focal or generalized papillary damage and loss of renal substance had occurred (Hodson, Drewe, Karn, and King, 1962).

Progressive damage was graded into three degrees of severity-slight, moderate, and marked. The criteria used for this grading were: depressed growth and/or focal damage was classified as slight, depressed growth and minor loss of renal substance as moderate, and depressed growth and severe loss of renal substance as marked damage (Table VI). These re-

TABLE VI.-Progressive Renal Damage

\begin{tabular}{|c|c|c|c|c|c|c|c|}
\hline \multirow{2}{*}{\multicolumn{3}{|c|}{$\begin{array}{l}\text { Type of } \\
\text { Reflux }\end{array}$}} & \multirow{2}{*}{ Kidneys } & \multicolumn{3}{|c|}{ Progressive Damage } & \multirow{2}{*}{ Total } \\
\hline & & & & Slight & Moderate & Marked & \\
\hline $\begin{array}{l}\text { Gross. . } \\
\text { Moderate } \\
\text { Slight }\end{array}$ & $\begin{array}{l}\ldots \\
\cdots\end{array}$ & $\begin{array}{l}. \\
\cdots \\
\therefore\end{array}$ & $\begin{array}{r}17 \\
\quad 34 \\
3\end{array}$ & 8 & 4 & 1 & 13 \\
\hline
\end{tabular}

sults show that only those kidneys associated with a grossly refluxing ureter had signs of progressive damage. It is of particular significance that progressive changes occurred in two kidneys with grossly refluxing ureters which had been considered normal at the initial examination (Figs. 1-4). No progressive damage was detected in kidneys associated with moderate or slight reflux.

\section{Follow-up Micturating Cystourethrograms}

Micturating cystourethrograms were repeated on 28 patients. In this group 35 refluxing ureters had been re-examined 


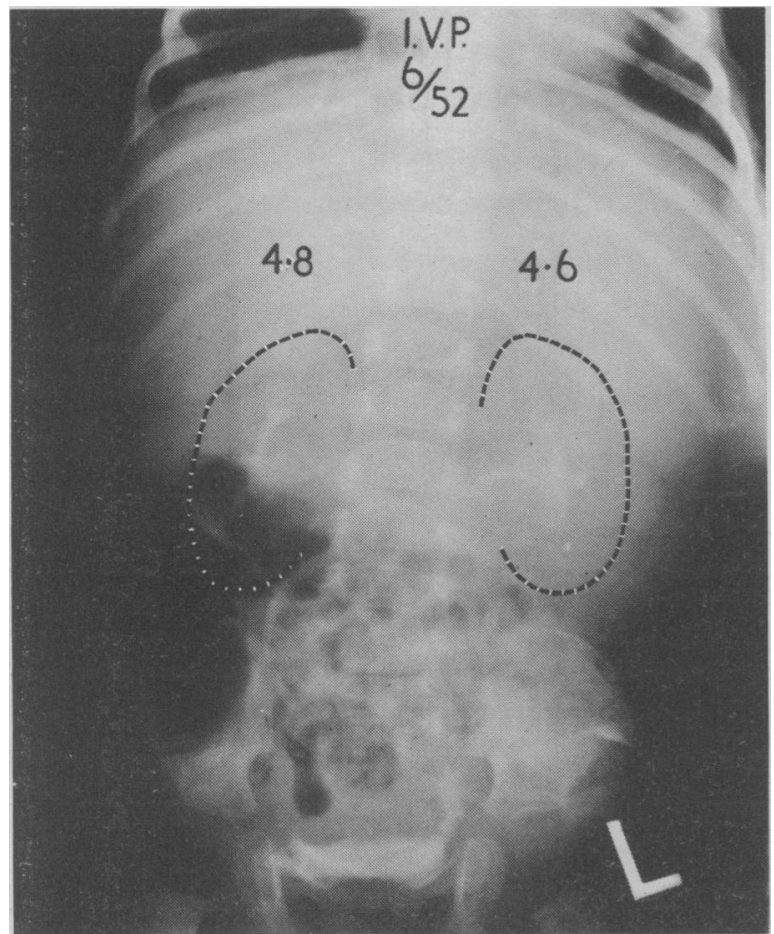

Fig. 1.-Intravenous pyelogram of a 6-week-old baby with acute pyelonephritis, showing no evidence of renal damage.

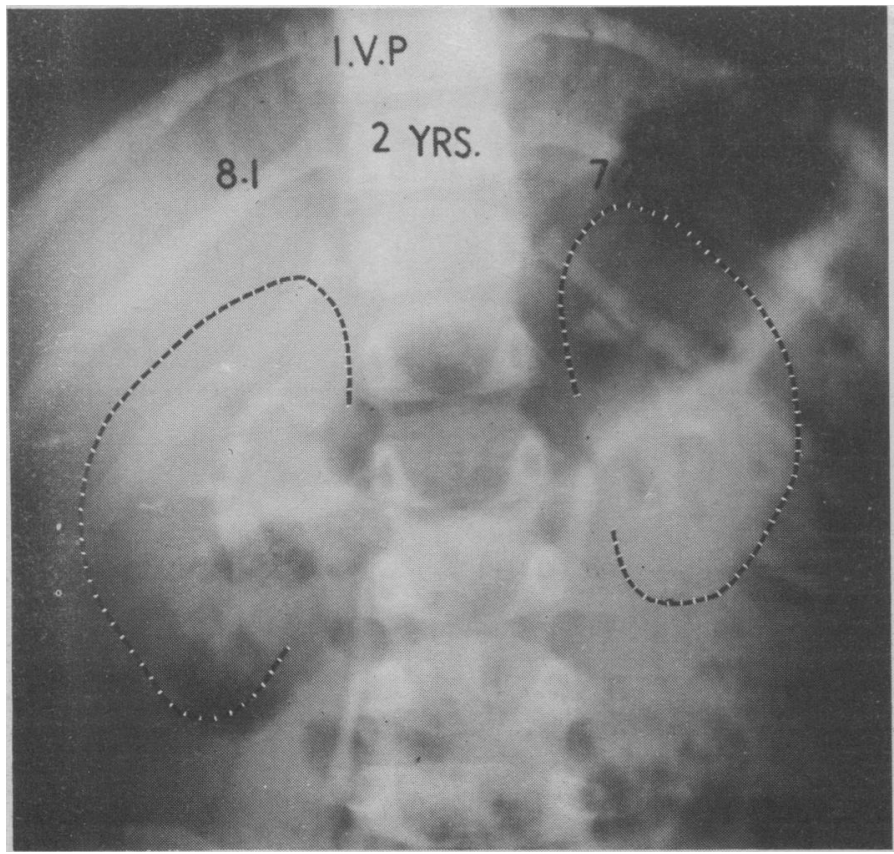

FIG. 3.- Intravenous pyelogram of same patient at 2 years, showing failure of growth of left kidney.

at intervals varying from six months to five years (Table VII). These follow-up examinations showed that the reflux had stopped in 19 out of 35 ureters but persisted in 16. Of the eight ureters which had initially shown gross reflux only one had stopped. An analysis of these follow-up examinations is given in Table VIII.

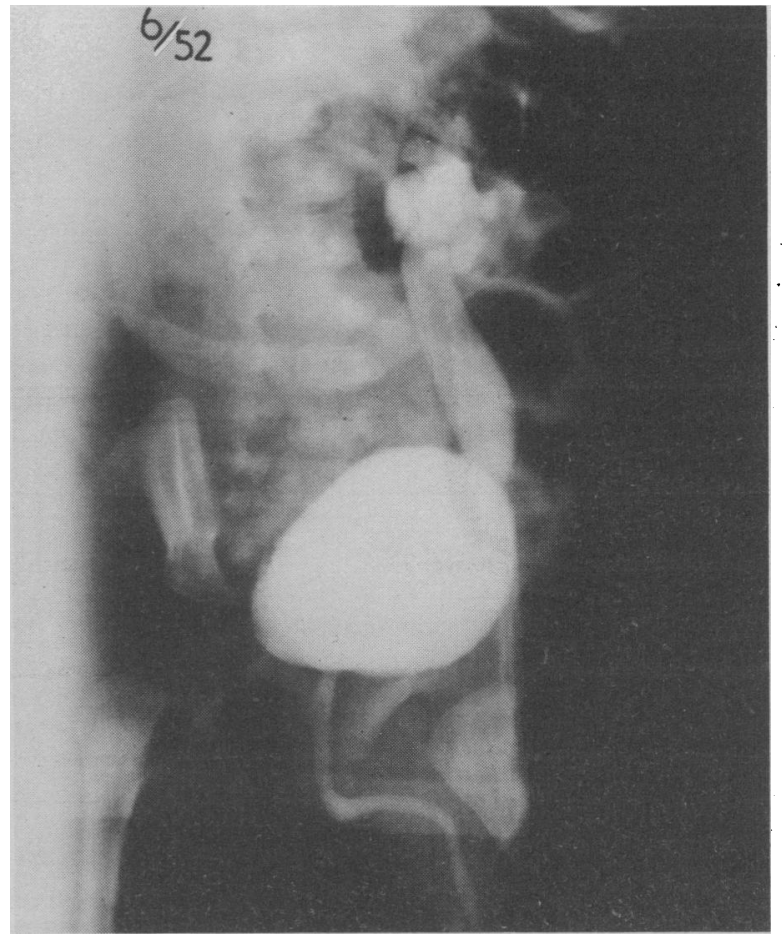

Fig. 2.-Micturating cystourethrogram of same patient illustrated in Fig. 1, showing gross vesicoureteric reflux in the left ureter.

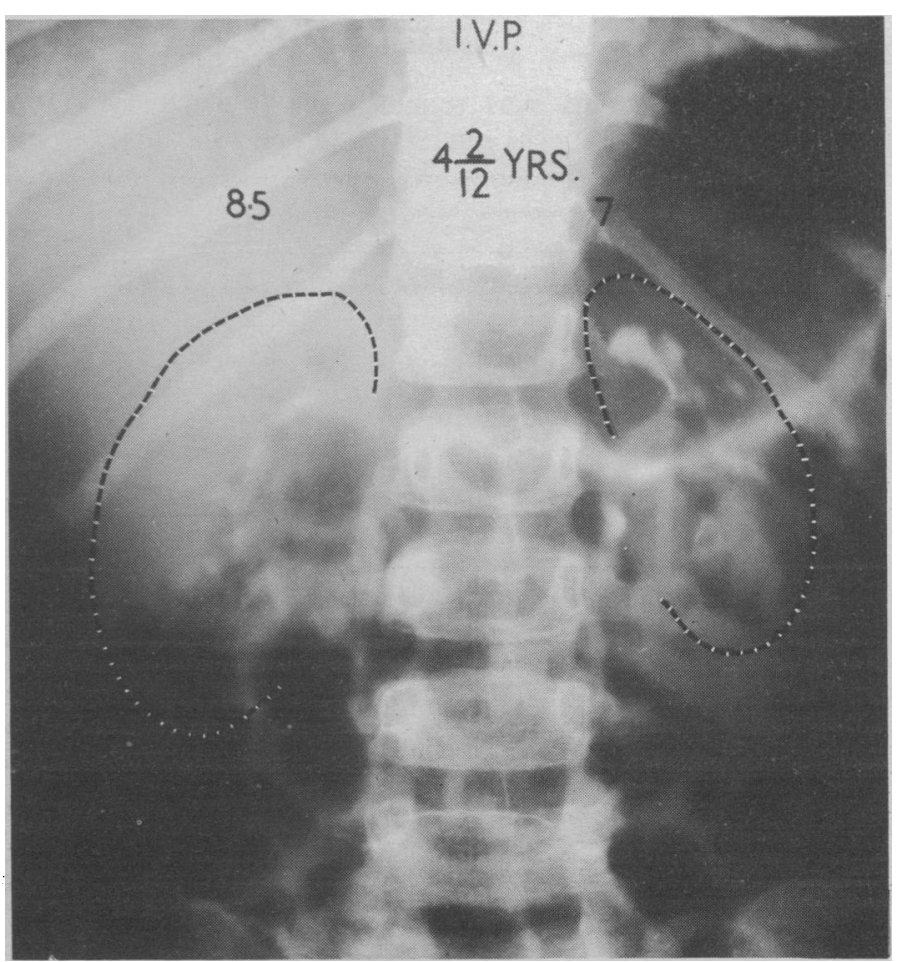

Fig. 4.- Intravenous pyelogram of same patient at 4 years 2 months, showing progression of renal damage. This infant remained free of infection throughout the period of observation.

TABLE VII.-Review Period of 35 Refluxing Ureters

\begin{tabular}{c|c|c|c|c}
\hline 6 months & 12 months & 2 years & 4 years & 5 years \\
\hline 8 & 5 & 9 & 2 & 11
\end{tabular}


TABLE VIII.-Follow-up Micturating Cystourethrograms of Gross and Moderate Reflux

\begin{tabular}{|c|c|c|c|c|c|c|}
\hline \multirow{2}{*}{\multicolumn{3}{|c|}{$\begin{array}{c}\text { Time } \\
\text { Interval }\end{array}$}} & \multirow{2}{*}{$\frac{\text { Gross }}{\substack{\text { Reflux } \\
\text { Ssopped }}}$} & \multirow{2}{*}{$\frac{\text { Reflux }}{\begin{array}{c}\text { Reflux } \\
\text { Continued }\end{array}}$} & \multicolumn{2}{|c|}{ Moderate Reflux } \\
\hline & & & & & $\begin{array}{l}\text { Reflux } \\
\text { Stopped }\end{array}$ & $\begin{array}{c}\text { Reflux } \\
\text { Continued }\end{array}$ \\
\hline $\begin{array}{l}6 \text { months } \\
12 \text { months } \\
2 \text { years .. } \\
4 \text { years } . \\
5 \text { years } . .\end{array}$ & $\begin{array}{l}\cdots \\
\cdots \\
\cdots \\
\cdots\end{array}$ & $\begin{array}{l}\cdots \\
\cdots \\
\cdots \\
\cdots\end{array}$ & 1 & $\begin{array}{l}1 \\
2 \\
2 \\
2\end{array}$ & $\begin{array}{l}4 \\
6 \\
2 \\
6\end{array}$ & $\begin{array}{l}3 \\
3 \\
1 \\
2\end{array}$ \\
\hline Total & . & . & 1 & 7 & 18 & 9 \\
\hline
\end{tabular}

\section{Discussion}

The classification of vesicoureteric reflux into the three grades of severity-gross, moderate, and slight-has provided a valuable guide on which treatment can be based. Our results have shown that the grossly refluxing ureter is accompanied by a high incidence of initial renal damage and, if this reflux is allowed to continue, may lead to depressed renal growth and further loss of renal substance.

The kidneys of ureters showing slight or moderate reflux do not appear to be associated with initial or progressive renal changes, but the numbers involved in this study are not sufficient to be certain of this point. Our findings, however, would suggest that this type of reflux in the infant has a reasonably good prognosis.

The results of follow-up micturating cystourethrograms would support the opinion expressed by Stephens (1962) that there is a strong tendency for spontaneous cessation of reflux in the course of several years, and it may well be that the ureter showing moderate vesicoureteric reflux and renal damage in childhood was, in fact, a grossly refluxing ureter in infancy.

Most writers have strongly emphasized the part that infection plays in producing the renal damage, and there can be little doubt that vesicoureteric reflux is an important mechanism by which infection of the bladder reaches the kidney. In support of this concept is the finding of pyelotubular backflow of contrast into segments of the renal parenchyma which we found on several occasions during micturating cystourethrography. Hodson (1965) concluded that coarse focal scarring begins in early childhood in most cases and is due to infection. In only 3 of the 29 damaged kidneys in our infant group, however, were the changes of a focal nature; in the remainder the damage was generalized. This would suggest that the hydrodynamic effect of vesicoureteric reflux is an important factor in producing renal damage in the prenatal and neonatal period. It seems probable that the continuing insult of the refluxing ureter may result in depressed growth and atrophy of the sensitive developing renal tissue.

Though most of our patients with gross vesicoureteric reflux suffered from recurring infection in the follow-up period there were two examples of progressive generalized renal damage in children who had remained free of infection during the five-year follow-up period and whose initial pyelograms had shown no evidence of renal damage. In both cases regular bacteriological examination of urine had been negative over the follow-up period. Fig. 1 shows one of these cases.

The evidence that has resulted from this follow-up study would indicate that the contracted atrophic "pyelonephritic" kidney of children and adults is the result of gross vesicoureteric reflux in infancy. We have also shown that if gross vesicoureteric reflux is allowed to persist progressive renal damage may occur in apparently normal infant kidneys as well as in those showing initial damage. It would appear, therefore, that the grossly refluxing ureter of infancy is potentially dangerous to the kidney and should be surgically corrected as soon as possible. There would not appear to be any indication to correct moderate or slight reflux.

\section{REFERENCES}

Hodson, C. J. (1965). Proceedings of the Royal Society of Medicine, 58, 785.

Hodson, C. J., Drewe, J. A., Karn, M. N., and King, A. (1962). Archives of Disease in Childhood, 37, 616.

Little, P. J., McPherson, D. R., and de Wardener, H. E. (1965). Lancet, 1, 1186.

Scott, J E. S., and Stansfeld, J. M. (1968). Archives of Disease in Childhood, 43, 323.

Shannon, F. 'T., Sepp, E., and Rose, G. R. (1969). Australian Paediatric fournal, 5, 97.

Stephens, D. S. (1963). Fournal of the College of Radiologists of Australasia, $7,17$.

\title{
Use of Oral Mannitol in the Oedematous Patient
}

\author{
J. W. JAMES, ${ }^{*}$ M.R.A.C.P. ; R. A. EVANS, $†$ M.R.A.C.P.
}

British Medical fournal, 1970, 1, 463-465

Cummary: Oral mannitol 200 g. was given on 24 $\checkmark$ occasions to patients with intractable oedema (cardiac, renal, or hepatic) and produced a mean weight loss of $3 \mathbf{~ k g}$. The procedure was found to be a safe, rapid, and effective method of treating oedema, and it should be used when diuretic therapy proves ineffective, particularly in the presence of hyponatraemia.

\section{Introduction}

Most oedematous patients respond to bed rest, salt restriction, digitalization (if indicated), and moderate doses of diuretics.

* Medical Officer.

†Specialist Resuscitation.

Repatriation General Hospital, Concord, New South Wales, Australia.
Some who are refractory to these measures respond to large doses of potent diuretics (Maher and Schreiner, 1965). If even these fail, mechanical methods of fluid removal become necessary-peritoneal dialysis, abdominal paracentesis, or even Southey tubes.

This paper describes our experience with oral mannitol in a group of patients refractory to medical therapy and attempts to define its place in the treatment of oedema.

\section{Patients and Methods}

Sixteen patients were treated with oral mannitol on 25 occasions. Nine had congestive cardiac failure, six had advanced renal failure, and one had cirrhosis of the liver. All patients, however, had both cardiomegaly and some degree of azotaemia, the lowest blood urea level being $70 \mathrm{mg}$. $/ 100 \mathrm{ml}$. They 